\title{
Does a Specific Location of Composted Poultry Litter in Soil Influence Nutrient Use Efficiency and Vegetable Production? A Mesocosm Experiment
}

\author{
Bernard Y. Koffi ${ }^{1}$, Armand W. Koné ${ }^{1}$, Seydou Tiho ${ }^{2}$, Fulgence Kouadio ${ }^{1} \&$ Dominique Masse $^{3}$ \\ ${ }^{1}$ UR Gestion Durable des Sols, Université Nangui Abrogoua, Abidjan, Côte d'Ivoire \\ ${ }^{2}$ UR Ecologie et Biodiversité, Université Nangui Abrogoua, Abidjan, Côte d'Ivoire \\ ${ }^{3}$ ECO\&SOLS, IRD, INRA, CIRAD, SUPAGRO, Université de Montpellier, Montpellier, France \\ Correspondence: Bernard Y. Koffi, UR Gestion Durable des Sols, Université Nangui Abrogoua, Abidjan, 02 BP \\ 801 Abidjan 02, Côte d'Ivoire. Tel: 00225-4840-1785. E-mail: bernardkoffi1@gmail.com
}

Received: October 30, $2017 \quad$ Accepted: December 15, $2017 \quad$ Online Published: January 15, 2018

doi:10.5539/jas.v10n2p167 URL: https://doi.org/10.5539/jas.v10n2p167

The research was financed by the Institut de Recherche pour le Développement (IRD) and the Programme d'Appui Stratégique à la Recherche Scientifique en Côte d'Ivoire (PASRES) through the project ERAfrica-ConneSSA.

\begin{abstract}
Animal wastes may be promoted as an alternative to mineral fertilizers that remain unaffordable to the overwhelming part of smallholder farmers in Sub-saharan Africa. However for an efficient use, mechanisms that underly their impact on crops should be well understood. This study was conducted in mesocosm to evaluate impacts of two ways of composted poultry litter (CPL) addition on growth and nutrient use efficiency by cucumber. It included three treatments with five-bucket replicates each: Control, CPL applied on soil surface (CS) or buried to $10 \mathrm{~cm}$-depth (CB). Dry CPL was added at the rate of $0.5 \mathrm{~kg}_{\text {bucket }}{ }^{-1}$. At harvest, root distribution was examined in the 0-5, 5-10 and 10-20 cm depths. Dry biomasses of roots, shoot and fruits were also determined and allowed for calculation of diverse indexes of biomass allocation (root:shoot ratio, root weight ratio, stem weight ratio, leaf weight ratio) and nutrient use efficiency (factor productivity of the compost, partial factor productivity of nutrients, agronomic efficiency of compost, and apparent agronomic efficiency of nutrients). The results showed that application of CPL led to a significant improvement of all considered parameters except for the leaf weight ratio which was higher in the control (44.1 \pm 3.3$)$ than in CS (28.1 \pm 1.9$)$ and CB 31.2 \pm 3.5$)$. Total lateral root length was significantly higher in CS than in CB $(113.5 \pm 10.7 \mathrm{~cm} \mathrm{vs.75.5 \pm 9.0}$ $\mathrm{cm}$ ). The number of lateral roots per plant in the $0-5 \mathrm{~cm}$ soil layer was higher in CS than in CB (5.4 vs. 1 root plant $\left.^{-1}\right)$; the reverse was observed in $5-10 \mathrm{~cm}\left(1.2 \mathrm{vs} .4 .4\right.$ root plant $\left.^{-1}\right)$. Both fresh fruit yield and total dry mass were positively correlated to root attributes. These were themselves negatively impacted by soil acidity. All nutrient use efficiency indexes were higher in CS than CB. The CPL improved the agronomic performance of cucumber particularly when applied at soil surface.
\end{abstract}

Keywords: composted poultry litter, nutrient use efficiency, roots distribution, agro-ecology, cucumber

\section{Introduction}

In sub-Saharan Africa, market gardening is an income-generating activity for urban and peri-urban farmers. This activity essentially supplies urban markets with fresh vegetables (Onana, 2006) such as cucumber (Cucumis sativus L.), tomato (Solanum lycopersicum), carot (Daucus carota), cabbage (Brassica oleracea), lettuce (Lactuca sativa), etc., thereby contributing to food security. Peri urban agriculture is more and more intensive as observed in other sub-Saharan African countries, because of increasing food needs (Kasongo et al., 2013). In such situation, soil nutrient removals should be offset by inputs to maintain the soil fertility. Thus, conventional solutions in particular mineral fertilization were proposed. This way, although effective in the short term remains unaffordable to the overhelming part of small farmers because of the relatively high cost (Haefele et al., 2013). In addition, the use of this kind of fertilizer leads to environmental concerns (Miranda et al., 2015; Celik et al., 
2010; Lee et al., 2013). In this context, organic fertilization may be considered as an appropriate solution for sustainable crop production (Chang et al., 2014).

Intensified livestock development in periurban zone as poultry livestock offers large resource of organic matter to be recycled. Market gardening soils are being increasingly fertilized with poultry droppings, which are likely to provide an interesting contribution to cultivated soils. About $70 \%$ of the nitrogen and phosphorus ingested by poultry is returned through droppings (Chabelier et al., 2006). Also, poultry droppings are increasingly preferred by farmers compared to other animal droppings because of their high macroelement content (Duncan, 2005). Although animal wastes have been used as manure for long times world-wide (López-Masquera et al., 2008), very few studies have focused on the potential impacts of composted poultry litter (CPL) on vegetable crop yield. Indeed, the composted form is known to provide more uniform substrate and stable organic matter that promotes greater soil C sequestration as opposed to noncomposted poultry manure (Peltre et al., 2010; Bouajila \& Sanaa, 2011). Also, studies that focused on the efficiency of nutrient use according to the way of CPL application are scarce. This gap should be filled in since the location of organic fertilizer at the soil surface or deeper in the soil may influence the dynamic of soil organic matter and nutrient with implication for crop mineral nutrition (Adekya \& Agbede, 2016).

Organic matter is known to influence soil properties in terms of structure and water dynamics (Islam et al., 2017; Liu et al., 2017). In organic fertilization, the location of organic residues has important implications for the soil organic matter building up and soil fertility. The fate of this organic residue may be linked to its status. Fresh materials were reported to be subjected to faster decomposition and release of $\mathrm{N}$ when buried in the soil (Jahanzad et al., 2016). However, concerning more stable residue such as composts, burial may appear less favourable for decomposition compared to surface application (Wang et al., 2014). In the latter case, key nutrient such as nitrogen is preserved from loss through volatilization and may result in improved crop production (Adekya \& Agbede, 2016). Here, the research question relates to the influence of the way of CPL application on plant root development, biomass allocation and yield. The main hypothesis was that the agronomic efficiency of CPL differs according to location in the soil.

\section{Material and Methods}

\subsection{Study Site}

The study took place at the experimental site of the University Nangui Abrogoua, Abidjan $\left(5^{\circ} 00^{\prime}\right.$ and $5^{\circ} 30^{\prime} \mathrm{N}$, $3^{\circ} 50^{\prime}$ and $4^{\circ} 10^{\prime} \mathrm{W}$ ) (Figure 1). The climate is of equatorial type with atmospheric humidity of $90 \%$ to $100 \%$. Average annual rainfall and temperature are $1700 \mathrm{~mm}$ and $27.3^{\circ} \mathrm{C}$ respectively.

\subsection{Poultry Manure Composting}

Poultry litter was composted in aerobic conditions at the agricultural training center of Tshanfeto $\left(5^{\circ} 20^{\prime} 12^{\prime \prime} \mathrm{N}\right.$ and $4^{\circ} 7^{\prime} 57^{\prime \prime} \mathrm{W}$ ) located at the eastern outskirt of Abidjan. Watering and turning were carried out once every two weeks to ensure good conditions for substrate decomposition. After about 10 weeks, the mature compost was harvested, dried and transferred to Nangui Abrougoua University. The concentration and total amount of nutrients supplied are shown in Table 1.

Table 1. Nutrient concentration and quantity of nutrient supplied though composted poultry litter

\begin{tabular}{llllllll}
\hline & Org. matter & $\mathrm{C}$ & $\mathrm{N}$ & $\mathrm{P}$ & $\mathrm{K}$ & $\mathrm{Ca}$ & $\mathrm{Mg}$ \\
\hline Concentration $\left(\mathrm{g} \mathrm{kg}^{-1}\right)$ & 246.4 & 142.9 & 9.0 & 8.6 & 63.4 & 9.6 & 12.1 \\
Amount of nutrient supplied bucket $\left(\mathrm{g} \mathrm{bucket}^{-1}\right)$ & 123.2 & 71.4 & 4.5 & 4.3 & 31.7 & 4.8 & 6.1 \\
\hline
\end{tabular}

\subsection{Treatment Set-Up}

For the purpose of this study, top soil (dystric ferralsol) was collected in a fallow dominated by Panicum maximum (Andropogoneae) at the agricultural training center of Tshanfeto and transferred to Nangui Abrogoua University. The experimental unit was a $10 \mathrm{~L}$ bucket $(30 \mathrm{~cm}$ diameter) filled up with homogenized soil samples from Tshanfeto. The chemical characteristics of that soil were as follows: $\mathrm{C}=14.3 \mathrm{~g} \mathrm{~kg}^{-1}, \mathrm{~N}=1.3 \mathrm{~g} \mathrm{~kg}^{-1}, \mathrm{C} / \mathrm{N}=11$, available $\mathrm{P}=23.3 \mathrm{mg} \mathrm{kg}{ }^{-1}, \mathrm{~K}^{+}=0.1 \mathrm{cmol}_{\mathrm{c}} \mathrm{kg}^{-1}, \mathrm{Ca}^{2+}=1.3 \mathrm{cmol}_{\mathrm{c}} \mathrm{kg}^{-1}, \mathrm{Mg}^{2+}=0.3 \mathrm{cmol}_{\mathrm{c}} \mathrm{kg}^{-1}, \mathrm{CEC}=4.3 \mathrm{cmol}_{\mathrm{c}} \mathrm{kg}^{-1}$, $\mathrm{V}=42.5 \%, \mathrm{pH}=4.3$.

Prior to filling the buckets, the bottom was drilled with five $2 \mathrm{~cm}$-diameter holes to allow for good drainage. The buckets were then exposed to open air for cucumber plants to grow under ambient weather. The experiment 
included three treatments with five replicates each: buckets with CPL spread on entire soil surface (CS) or buried in holes (20 cm length, $20 \mathrm{~cm}$ width and $10 \mathrm{~cm}$ deep) (CB), and a control (without any addition). Dry CPL was applied at the rate of $0.5 \mathrm{~kg}$ per bucket for both $\mathrm{CS}$ and $\mathrm{CB}$ treatments.

\subsection{Cucumber Growth Conditions and Yield Measurement}

One day after CPL addition, cucumber (variety Tokyo) was sown at the rate of three seed holes per bucket. The experimental plot and buckets were maintained weed-free through regular weeding. Buckets were watered every two days with $1 \mathrm{~L}$ water throughout the growing period (February to March 2017). However, when rainfall event occurred during obout $30 \mathrm{~min}$, buckets were watered four days after. When fruit reached maturity (60 days after sowing), cucumber plants were harvested and oven-dried at $60{ }^{\circ} \mathrm{C}$ to constant weight. Then, dry root, shoot and fruit dry yields were determined.

\subsection{Root Development and Distribution}

At harvest, root development and distribution was examined on one individual plant per bucket. For each bucket, one side was uncovered over an arc of $20 \mathrm{~cm}$ rope, then the block of soil at that side was pickled to bring out roots along the soil profile. This profile was subdivided into three layers $(0-5 \mathrm{~cm}, 5-10 \mathrm{~cm}$ and $10-20 \mathrm{~cm})$ where lateral roots (or first order ramification, directly attached to the taproot) were counted. Their length was measured using a graph paper.

\subsection{Determination of Biomass Allocation and Nutrient Use Efficiency Indexes}

Allocation of resources by cucumber was assessed through diverse ratios:

- Root weight ratio (RWR);

- Stem weight ratio (SWR);

- Leaf weight ratio (LWR);

- Root:shoot ratio (R:S) = $\mathrm{DM}_{\mathrm{root}} / \mathrm{DM}_{\text {shoot(stem, leaf and fruit); }}$

- Harvest Index (HI): Dry fruit mass to total dry plant mass: $\mathrm{HI}(\%)=\left(\mathrm{MS}_{\text {fruit }} / \mathrm{MS}_{\text {plant }}\right)$.

Diverse nutrient use efficiency was calculated through production efficiencies indexes. In all these equations, fertilizer refers to CPL.

- Fertilizer productivity or factor productivity $(\mathrm{FP})=[$ total dry mass yield $(\mathrm{kg}) /$ amount of fertilizer supplied $(\mathrm{kg})]$;

- Partial factor productivity of applied nutrient $(\mathrm{PFP})=$ [total dry mass yield $(\mathrm{kg}) /$ amount of nutrient supplied $(\mathrm{kg})]$;

- Agronomic efficiency (AE): [dry biomass yield with fertilization $(\mathrm{kg})$ - dry biomass without fertilization $(\mathrm{kg})] /$ amount of fertilizer supplied $(\mathrm{kg})$;

- Apparent agronomic efficiency of nutrient $(\mathrm{AAE})=[$ dry biomass yield with fertilization $(\mathrm{kg})$ - dry biomass without fertilization $(\mathrm{kg})] /$ amount of nutrient supplied $(\mathrm{kg})$.

\subsection{Soils Sampling for $\mathrm{pH}$ Measurement}

Water $\mathrm{pH}$ was measured on the initial soil used for the experiment using a glass electrode in $1 / 2.5$ soil/water ratio as described by Thomas (1996). At the end of the cucumber cycle, soil was sample in each bucket at the 0-10 and $10-20 \mathrm{~cm}$ depths and also subjected to $\mathrm{pH}$ measurement. Prior to this, samples were air-dried at ambient temperature, crushed and sieved at $2 \mathrm{~mm}$.

\subsection{Statistical Analyses}

Yields, biomass allocation ratios and nutrient efficiency indexes were compared using one-way analysis of variance (ANOVA) after verification of the homogeneity of the variances (Levene test) and log-transformation of data where needed. When differences were significant, mean separation was done using Student-Newman-Keuls test at 5\%. All these tests were done using the Statistica 7.1. Results were significant when $\mathrm{p}<0.05$.

\section{Results}

\subsection{Soil pH in the Different Treatments at the End of Trials}

Soil $\mathrm{pH}$ at the end of trials significantly differed between treatments $(\mathrm{p}<0.001)$. Values were higher in soil with compost addition compared to the control (Table 2). For the same soil layer, there was no significant difference between CS and CB. In each of the treatments, $\mathrm{pH}$ in $0-10 \mathrm{~cm}$ layer was significantly higher than in the $10-20 \mathrm{~cm}$ (CS: $5.5 \pm 0$ vs. $4.5 \pm 0$ for CS; CB: $5.4 \pm 0.1$ vs. $4.6 \pm 0.1$ ). 


\subsection{Root Development and Distribution}

\subsubsection{Root Development}

Addition of CPL resulted in a significant increase of taproot length and collar diameter relative to the control (Table 3). Density, total length and mean length of lateral roots also increased significantly. The collar diameter of the taproot and total lateral roots length in CS was significantly higher than in CB.

Table 2. Change in soil acidity between the start and the end of the cucumber cropping cycle

\begin{tabular}{lllll}
\hline \multirow{2}{*}{ Treatments } & \multicolumn{3}{c}{ Period of the cucumber cycle } & \multirow{2}{*}{ Student $t, \mathrm{p}$} \\
\cline { 2 - 4 } & Start & 4.3 & End & 0.894 \\
\hline Control & $0-10 \mathrm{~cm}$ & 4.3 & $4.3(0.1)$ & $<0.001$ \\
$\mathrm{CS}$ & $10-20 \mathrm{~cm}$ & 4.3 & $5.5(0.0)$ & 0.001 \\
\hline $\mathrm{CB}$ & $0-10 \mathrm{~cm}$ & 4.3 & $4.5(0.0)$ & $<0.001$ \\
& $10-20 \mathrm{~cm}$ & 4.3 & $5.4(0.1)$ & 0.003 \\
\hline
\end{tabular}

Note. Values in parentheses are standard errors. CS: compst applied at the soil surface, CB: buried compost.

Table 3. Cucumber root growth parameters [Mean(SE)]

\begin{tabular}{|c|c|c|c|c|c|}
\hline \multirow{2}{*}{ Parameters } & \multicolumn{3}{|c|}{ Treatments } & \multicolumn{2}{|c|}{ Anova } \\
\hline & Control & $\mathrm{CS}$ & $\mathrm{CB}$ & $F_{(2,12)}$ & p-value \\
\hline \multicolumn{6}{|l|}{ Taproot } \\
\hline Length $(\mathrm{cm})$ & $18.7(0.6) b$ & $35.4(3.7) \mathrm{a}$ & $41.6(3.1) \mathrm{a}$ & 10.0 & $<0.001$ \\
\hline Collar diameter $(\mathrm{mm})$ & $1.5(0.1) \mathrm{c}$ & $3.0(0.2) \mathrm{a}$ & $2.4(0.1) b$ & 29.8 & $<0.001$ \\
\hline \multicolumn{6}{|l|}{ Lateral roots } \\
\hline Density (root plant ${ }^{-1}$ ) & $3(0.2) b$ & $9.8(0.9) \mathrm{a}$ & $7.8(1.0) \mathrm{a}$ & 18.5 & 0.002 \\
\hline Total length $(\mathrm{cm})$ & $12.2(1.3) \mathrm{c}$ & 113.5 (10.7) a & $75.5(9.0) b$ & 40.2 & $<0.001$ \\
\hline Mean length $(\mathrm{cm})$ & $4.1(0.4) b$ & $12.0(1.7) \mathrm{a}$ & $10.0(1.2) \mathrm{a}$ & 10.9 & 0.002 \\
\hline
\end{tabular}

Note. In the same row, means with different letters are significantly different at the 0.05 level. CS: compst applied at the soil surface, CB: buried compost.

\subsubsection{Root Distribution}

In general, addition of CPL led to increased number of lateral roots (Figure 1). Root distribution was heterogeneous throughout the soil profile, and was influenced by the CPL application way. In the $0-5 \mathrm{~cm}$ soil layer, the number of lateral roots was significantly higher $(\mathrm{p}<0.0001 ; \mathrm{F}=46.3)$ in $\mathrm{CS}(5.4 \pm 0.5)$ than in the control (1.2 \pm 0.2$)$ and $\mathrm{CB}(1 \pm 0.3)$. 


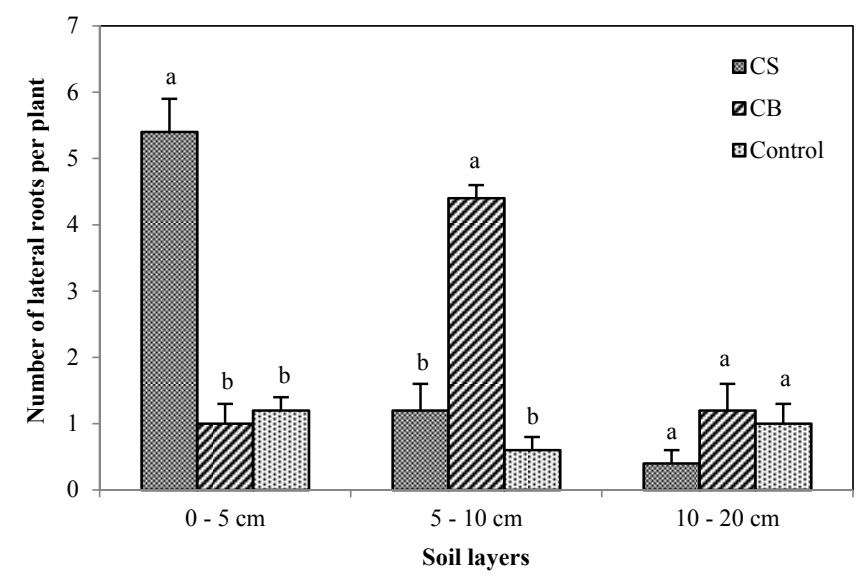

Figure 1. Roots distribution in the soil profile under the different treatments

Note. CS: compst applied at the soil surface, CB: buried compost.

In the $5-10 \mathrm{~cm}$ soil layer, the highest number $(\mathrm{p}<0.0001 ; \mathrm{F}=48.15)$ was rather observed in $\mathrm{CB}(4.4 \pm 0.2)$, followed by CS $(1.2 \pm 0.4)$ and the control $(0.6 \pm 0.2)$. The number of lateral roots was lower in the $10-20 \mathrm{~cm}$ soil layer than in $0-10 \mathrm{~cm}$ and did not show any significant difference $(\mathrm{p}=0.2 ; \mathrm{F}=1.7)$ among treatments. Pearson correlation test showed that the number of cucumber roots strongly increased with soil $\mathrm{pH}$ (Figure 2).

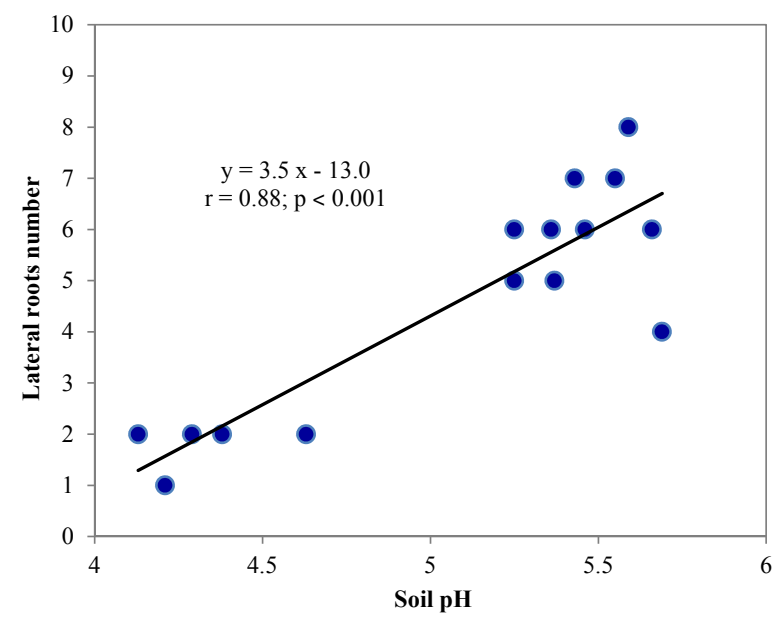

Figure 2. Correlation between soil acidity and lateral root density

\subsection{Cucumber Biomass Yield}

Both fresh fruit and total dry biomass yields were significantly higher on amended soils (CS, CB) as opposed to the control (fresh fruit yield: $\mathrm{p}=0.008$; Total dry biomass yield: $\mathrm{p}=0.007$ ) (Figure $3 \mathrm{a}, \mathrm{b}$ ). However, no significant difference was observed between CS and CB although fresh fruit yield and total dry biomass were $22.1 \%$ and $51.2 \%$ higher on the former than on the latter, respectively. Both fresh fruit and total dry biomass yield were very low on control $(0.04 \pm 0.00 \mathrm{~kg}$ per bucket and $0.007 \pm 0.00 \mathrm{~kg}$ per bucket, respectively).

Pearson correlation tests revealed that both fresh fruit and dry shoot biomass yields were significantly positively correlated to roots development parameters (Figures $4 \mathrm{a}$ to $4 \mathrm{f}$ ), particularly dry root mass and mean lateral root length. 

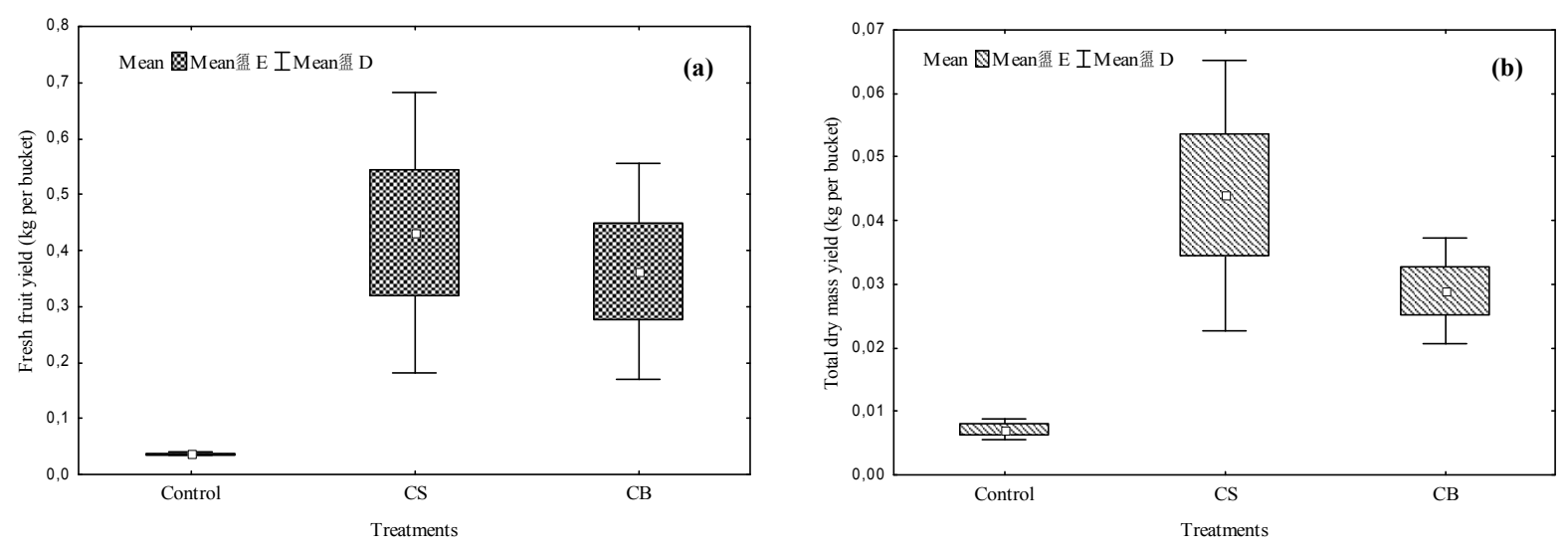

Figure 3. Fresh fruit yield (a) and total dry biomass yield (b) in the different treatments Note. CS: compst applied at the soil surface, CB: buried compost.
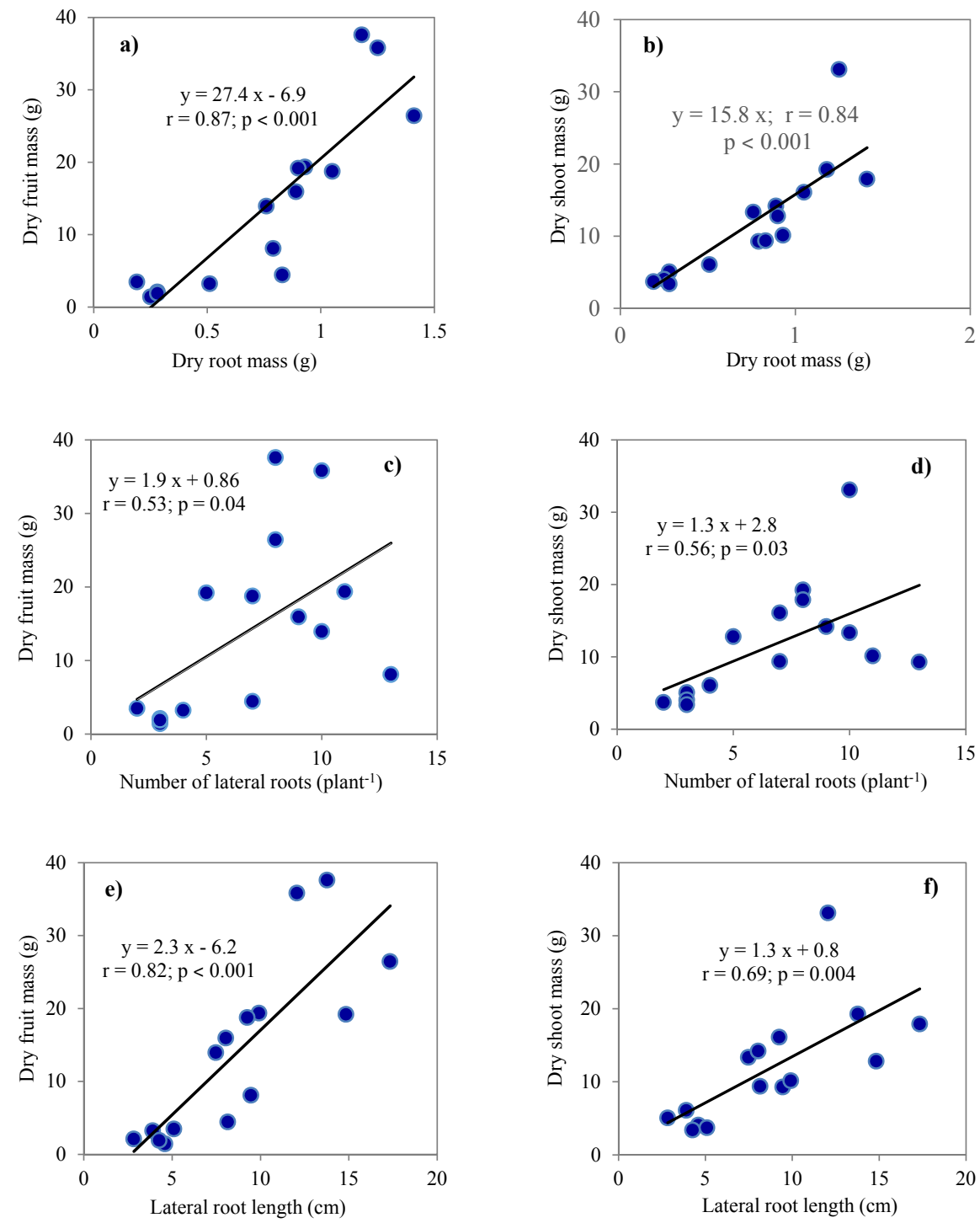

Figure 4. Correlation between root attributes and cucumber dry mass yields 


\subsection{Biomass Allocation Indexes}

No significant difference was observed between treatments for Root:Shoot ratio, root weight ratio and stem weight ratio $(\mathrm{p}=0.19 ; \mathrm{p}=0.18 ; \mathrm{p}=0.26$ respectively) although these parameters were relatively higher in the control (Table 4). In turn, leaf weight ratio was significantly $(p=0.006)$ higher in the control than in CS and CB.

Table 4. Indexes of biomass allocation by cucumber [Mean(SE)]

\begin{tabular}{lllllll}
\hline & \multicolumn{3}{c}{ Treatments } & & \multicolumn{2}{c}{ Anova } \\
\cline { 2 - 4 } & Control & CS & CB & & $F_{(2,12)}$ & $p$ \\
\hline Root:Shoot ratio (R/S) (\%) & $4.4(0.5) \mathrm{a}$ & $2.9(0.5) \mathrm{a}$ & $3.6(0.6) \mathrm{a}$ & & 1.9 & 0.19 \\
Root weight ratio (RWR) (\%) & $4.2(0.5) \mathrm{a}$ & $2.8(0.4) \mathrm{a}$ & $3.4(0.6) \mathrm{a}$ & & 2.0 & 0.18 \\
Leaf weight ratio (LWR) (\%) & $44.1(3.3) \mathrm{a}$ & $28.1(1.9) \mathrm{b}$ & $31.2(3.5) \mathrm{b}$ & & 7.9 & 0.01 \\
Stem weight ratio (SWR) (\%) & $18.3(2.0) \mathrm{a}$ & $15.5(1.4) \mathrm{a}$ & $14.2(1.7) \mathrm{a}$ & & 1.5 & 0.26 \\
\hline
\end{tabular}

Note. In the same row, means with different letters are significantly different at the 0.05 level. CS: compst applied at the soil surface, CB: buried compost.

\subsection{Harvest Index}

Harvest index under CPL addition (CS and CB) was significantly higher $(\mathrm{p}=0.01)$ than in the control (Figure 5). However, no significant difference was observed between CS and CB.

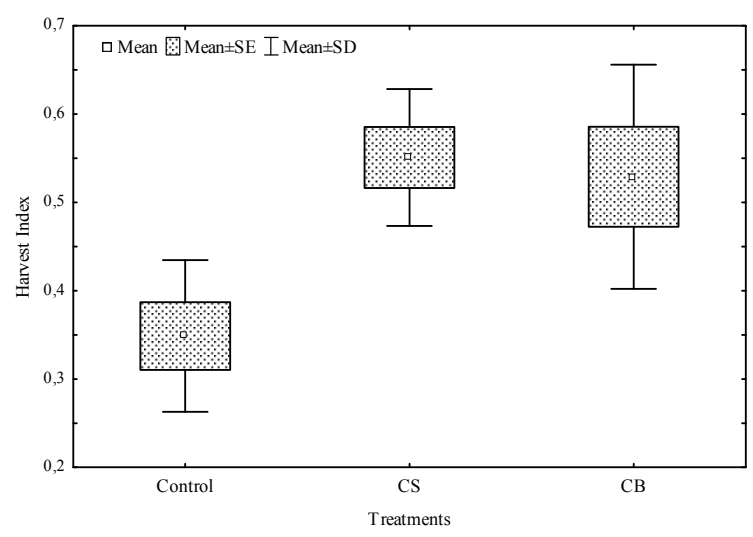

Figure 5. Cucumber harvest index on the different treatments

Note. CS: compst applied at the soil surface, CB: buried compost.

\subsection{Nutrient Use Efficiency (NUE) Indexes}

With respective increments of $33.3 \%$ and $100 \%$, productivity efficiency and agronomic efficiency of CPL were higher in CS compared to CB (Table 5). Partial factor productivities for CPL-N, -P and -K were 53.1\%, 54.5\% and $40 \%$ higher in CS than CB. The same trends were observed for apparent agronomic efficiencies (AAE) that were $70.8 \%, 72 \%$ and $100 \%$ higher in CS relative to CB. The agronomic efficiency of the CPL was also $100 \%$ higher in CS relative to $\mathrm{CB}$.

\section{Discussion}

The low fresh fruit and total dry biomass yields on the control indicates that original soil at Tshanfeto was nutrient-poor and unsuitable for adequat cucumber development. Acidic soil condition could also be the reason for poor cucumber growth and development. Indeed, data of the present study showed that low soil $\mathrm{pH}$ led to limited lateral root development. In addition such soil condition is known to reduce the availability of nutrients, particularly exchangeable cations that are determinant in cucumber growth and fruit production as recently reported by Abobi et al. (2018). 
Table 5. Indexes of composted poultry litter-derived nutrient use efficiency by cucumber

\begin{tabular}{|c|c|c|}
\hline \multirow{2}{*}{ Parameters } & \multicolumn{2}{|c|}{ Treatments } \\
\hline & $\overline{\mathrm{CS}}$ & $\mathrm{CB}$ \\
\hline \multicolumn{3}{|c|}{ Partial Factor Productivity of nutrient (PFP) } \\
\hline $\mathrm{N}\left(\mathrm{kg} \mathrm{kg}^{-1}\right)$ & 9.8 & 6.4 \\
\hline $\mathrm{P}\left(\mathrm{kg} \mathrm{kg}^{-1}\right)$ & 10.2 & 6.6 \\
\hline $\mathrm{K}\left(\mathrm{kg} \mathrm{kg}^{-1}\right)$ & 1.4 & 1.0 \\
\hline \multicolumn{3}{|c|}{ Fertilizer productivity } \\
\hline $\mathrm{FP}\left(\mathrm{kg} \mathrm{kg}^{-1}\right)$ & 0.08 & 0.06 \\
\hline \multicolumn{3}{|c|}{ Apparent Agronomic Efficiency of nutrient (AAE) } \\
\hline $\mathrm{N}\left(\mathrm{kg} \mathrm{kg}^{-1}\right)$ & 8.2 & 4.8 \\
\hline$P\left(\mathrm{~kg} \mathrm{~kg}^{-1}\right)$ & 8.6 & 5.0 \\
\hline $\mathrm{K}\left(\mathrm{kg} \mathrm{kg}^{-1}\right)$ & 1.2 & 0.6 \\
\hline \multicolumn{3}{|c|}{ Agronomic Efficiency of fertilizer $(A E)$} \\
\hline $\mathrm{AE}\left(\mathrm{kg} \mathrm{kg}^{-1}\right)$ & 0.08 & 0.04 \\
\hline
\end{tabular}

Note. CS: compst applied at the soil surface, CB: buried compost.

Conversely, the increase in fresh fruit and total dry biomass yields following CPL addition indicated that this organic residue was able to overcome the above-mentioned constrains. Concentrations of exchangeable cations, especially in $\mathrm{K}^{+}\left(63.4 \mathrm{~g} \mathrm{~kg}^{-1}\right)$ make it a good fertilizer for cucumber which is known to be potassium-demanding (Morgan, 2016). The CPL was rich in terms of organic matter and nutrients that are known to promote root development (Nakamura et al., 2008). Root development is conducive to water and mineral nutrition, hence plant growth and biomass production. This is supported by our data since (i) density of lateral roots was the highest in the $0-5 \mathrm{~cm}$ layer in CS while it was so in the $5-10 \mathrm{~cm}$ layer $\mathrm{CB}$, and (ii) both fresh cucumber fruit yield and total dry mass were significantly and positively correlated to roots parameters (dry mass, mean length and number of lateral roots).

Another reason for the positive impact of CPL on cucumber growth and yield could be the significant rise of soil $\mathrm{pH}$ from very acidic to acidic on $\mathrm{CB}$ and CS, probably as a result of the supply of cations, particularly calcium as reported by Boating et al. (2006). As a matter of fact, soil acidity is known to control root development (Marschner et al., 2005) and this is confirmed by the significant correlation observed in the present study. The positive impact of CPL was also shown by Essehi et al. (2016) on rubber seedling growth, by Iren et al. (2015) on water-leaf growth and yield. Kimuni et al. (2014) found that cabbage yield obtained with $60 \mathrm{t} \mathrm{ha}^{-1}$ of CPL was similar to that with $350 \mathrm{~kg} \mathrm{ha}^{-1}$ of mineral fertilizers (NPK and urea).

Since root development proved influential on cucumber growth and biomass production, this parameters also may explain the difference observed between the two CPL application ways or locations in the soil. As cucumber roots are essentially superficial (FAO, 1988), spreading CPL on the entire surface of the CS buckets probably fostered root proliferation (lateral roots) and growth in length. This also allowed taproot growth in and width, explaining the higher collar diameter in CS than in CB. However, burying the CPL at $10 \mathrm{~cm}$ depth in CB buckets probably put the nutrients out of reach during the early stage of seedling development. Thus, the taproot had to grow in length to reach the nutrient source, resulting in increased length and lower collar diameter in $\mathrm{CB}$ as opposed to CS. Since the CPL was applied locally and at depth, lateral root development was restricted in CB as shown by the lower total lateral root length as compared to CS (Table 6). As a result, the efficiency of CPL-nutrient use by cucumber was higher in CS compared with CB, as reflected by values of the considered indexes. The better soil aeration at surface which is favorable to nutrient assimilation by roots (Huber \& Schaub, 2011) could also explain the higher agronomic efficiency of CPL in CS compared to CB. Lower mineralization rate of CPL incorporated into soil as reported by Kimuni et al. (2014) could also be explanatory. Therefore, it could be stated that soil surface is the right place for CPL application in cucumber cropping owing to a maximized effectiveness in nutrient use (Fixen \& Garcia, 2006).

Values of Harvest index that are higher than 0.5 reflect effective translocation of assimilates from the other parts of the plant to fruits (Lucas, 1984). The present study showed that CPL addition greatly contributed to this performance since $\mathrm{HI}$ associated with the control was quite lower while HIs associated with CS and CB were higher than this threshold. However, the similarity in HI values in CS and CB is attributable to the one in total dry biomass and dry fruit yields. 
According to Meziane (1997), Root:Shoot ratio is strongly influenced by the soil nutrient status. Therefore, in the original nutrient-poor soil from Tshanfeto, cucumber plant seems to have favoured root development for soil exploration rather than shoot development. This may explain why values of the ratio were to some extent higher in the control compared to the treatments with CPL addition. The same explanation might apply for the lower (even not significantly) values recorded in CS relative to CB. In CS, no significant effort was needed by the plant to access the nutrient source (CPL) since cucumber lateral roots are naturally shallow. In contrast, in $\mathrm{CB}$, the plant had to make an extra effort to develop roots in an unusual soil depth to access the nutrient source. Another reason for the higher Root:Shoot ratio was that fruit yield was lower, contributing to a lower aboveground biomass. In poor-soil conditions, other plant species such as leguminous were reported to direct greater effort in fruit production instead of non-reproductive parts (stem, roots, leaves) while in good soil conditions, they direct effort in non-reproductive organ production that allow them accessing light for the photosynthetic carbon assimilation (Meziane et al., 1997; Koné, 2009). However, in the present study with a species of the Cucurbitaceae family, the reverse phenomenon was observed as reflected by the higher values of Root weight ratio and the Leaf weight ratio in the control compared to CS and CB. The same reason could be mentioned for the higher values recorded in $\mathrm{CB}$ as opposed to CS.

\section{Conclusion}

This study showed that composted poultry litter greatly improved cucumber production owing to the quantity of nutrient it provided and the stimulation of root proliferation and development. Root development in turn was favoured by the reduction of the soil acidity and the presence of nutrients, and led to improved nutrient use efficiency.

The location of the CPL in the soil influenced the nutrient use efficiency as values of the indexes were higher when CPL was applied at the soil surface. This was favoured by the fact that cucumber roots are essentially shallow, thus no significant extra effort was directed towards root development at the expense of fruit. Although value of cucumber fresh fruit yield in $\mathrm{CS}$ was above that of $\mathrm{CB}$, statistical significance was not reached.

\section{References}

Abobi, H. D. A., Koné, A. W., Koffi, B. Y., Diahuissié, S. S. F., Loukou, S. K., \& Tiho, S. (2018). Soil Chemistry and Cucumber (Cucumis sativus L.) Yield as influenced by 16 years of Composted Poultry litter Addition. Journal of Agricultural Science, 10(1), 325-335. https://doi.org/10.5539/jas.v10n1p325

Adekiya, A. O., \& Agbede T. M. (2016). Effect of methods and time of poultry manure application on soil and leaf nutrient concentrations, growth and fruit yield of tomato (Lycopersicon esculentum Mill). Journal of the Saudi Society of Agricultural Sciences, 16(4), 383-388. https://doi.org/10.1016/j.jssas.2016.01.006

Boateng, S. A., Zickermann, J., \& Kornahrens, M. (2006). Poultry Manure Effect on Growth and Yield of Maize. West Africa Journal of Applied Ecology, 9, 12-18.

Bouajila, K., \& Sanaa, M. (2011). Effects of organic amendments on soil physico-chemical and biological properties. Journal of Materials and Environmental Science, 2, 485-490.

Celik, I., Gunal, H., Budak, M., \& Akpinar, C. (2010). Effects of long term organic and mineral fertilizers on bulk density and penetration resistance in semi-arid Mediterranean soil conditions. Geoderma, 160, 236-243. https://doi.org/10.1016/j.geoderma.2010.09.028

Chabelier, P. F., Kerchove, D. V. V., \& Macary, H. S. (2006). Guide de la fertilisation organique à la reunion (p. 51). CIRAD, Chambre d'Agriculture de la Réunion.

Chang E. H., Wang, C. H., Chen, C. L., \& Chung, R. S. (2014). Effects of long-term treatments of different organic fertilizers complemented with chemical $\mathrm{N}$ fertilizer on the chemical and biological properties of soils. Journal of Soil Science and Plant Nutrition, 6(4), 499-511. https://doi.org/10.1080/00380768.2014.917333

Duncan, I. J. H. (2005). Science-based assessment of animal welfare: Farm animals. Revue Scientifique et Technique-Office International des Epizooties, 24(2), 483-492. https://doi.org/10.20506/rst.24.2.1587

Essehi, J. L., Trazié, J. G. B., Koffi, E. K., Soumahin, E. F., Koffi, M. O., Obouayéba, S., \& Yao-Kouamé A. (2016). Impact de la fertilisation organique sur quelques caractéristiques du sol et les paramètres de croissance de l'Hévéa (Hevea brasiliensis Müll Arg.) en phase d'installation à Bouna dans le Sud de la Côte d'Ivoire. Inovative Space of Scientific Research Journals, 7(1), 143-154.

FAO. (1988). Cultures protégées en climat méditerranéen (p. 317). Rome. http://www.iamm.ciheam.org/ ress_doc/opac_css/index.php 
Fixen, P. F., \& Garcia, F. O. (2006). Effective nutrient management decisions looking beyond the next harvest. Proc. of $9^{\text {th }}$ AAPRESID Congress (pp. 181-187). Rosario, Argentina.

Haefele, S. M., Saito, K., N’Diaye, K. M., Mussgnug, F., Nelson, A., \& Wopereis, M. C. S. (2013). Increasing Rice Productivity through Improved Nutrient Use in Africa. In M. C. S. Wopereis, et al. (Eds.), Realizing Africa's Rice Promise. CAB International. https://doi.org/10.1079/9781845938123.0250

Huber, G., \& Schaub, C. (2011). La fertilité des sols: L'importance de la matière organique. Agricultures \& Territoires (p. 42). Service Environnement-Innovation, Chambre d'agriculture Bas-Rhin.

Iren, O. B, Akpan, J. F., Ediene, V. F., \& Asanga, E. E. (2015). Influence of cassava peels and poultry manure-based compost on soil properties, growth and yield of waterleaf (Talinum triangulare Jacq.) in an ultisol of south-eastern Nigeria. Journal of Soil Science and Environmental Management, 6(7), 187-194. https://doi.org/10.5897/jssem15. 0486

Islam, M. A., Islam, S., Akter, A., Rahman, M. H., \& Nandwani, D. (2017). Effect of organic and inorganic fertilizers on soil properties and the growth, yield and quality of tomato in Mymensingh, Bangladesh. Agriculture, 7, 18. https://doi.org/10.3390/agriculture7030018

Jahanzad, E., Barker, A. V., Hashemi, M., Eaton, T., Sadeghpour, A., \& Weis, S. A. (2016). Nitrogen Release Dynamics and Decomposition of Buried and Surface Cover Crop Residues. Agronomy Journal, 108, 1735-1741. https://doi.org/10.2134/agronj2016.01.0001

Kasongo, L. M. E., Mwamba, M. T., Tshipoya, M. P., Mukalay, M. J., \& Useni, S. Y. (2013). Réponse de la culture de soja (Glycine max L. (Merril) à l'apport des biomasses vertes de Tithonia diversifolia (Hemsley) A. Gray comme fumure organique sur un Ferralsol à Lubumbashi, R.D. Congo. Journal of Applied Biosciences, 63, 4727-4735. https://doi.org/10.4314/jab.v63i1.87247

Kimuni, L. N., Mwali, M. K., Mulembo, T. M., Lwalaba, J. L. W., \& Lubob, A. K. (2014). Effets de doses croissantes des composts de fumiers de poules sur, le rendement de chou de Chine installé sur un sol acide de Lubumbashi. Journal of Applied of Biosciences, 77, 6509-6522. https://doi.org/10.4314/jab.v77i1.4

Koné, A. W. (2009). Qualité des sols en zone de savane humide de Côte d'Ivoire: Utilisation des légumineuses herbacées comme alternative pour une valorisation des terres marginales et une agriculture durable (p. 195, PhD dissertation, Université d'Abobo-Adjamé, Abidjan).

Lee, C. H., Kang, S. S., Jung, K. Y., \& Kim, P. J. (2013). Effect of Long Term Fertilization on Microbial Biomass, Enzyme Activities, and Community Structure in Rice Paddy Soil. Korean J.ournal of Soil Science and Fertilizer, 46(6), 487-493. https://doi.org/10.7745/KJSSF.2013.46.6.487

Liu, Z., Rong, Q., Zhou, W., \& Liang, G. (2017). Effects of inorganic and organic amendment on soil chemical properties, enzyme activities, microbial community and soil quality in yellow clayey soil. PLoS One, 12(3), e0172767. https://doi.org/10.1371/journal.pone.0172767

López-Masquera, M. E., Cabaleiro, F., Sainz, M. S., López-Fabal, A., \& Carral, E. (2008). Fertilizing value of broiler litter: Effects of drying and pelletizing. Bioresource Technology, 99, 5626-5633. https://doi.org/ 10.1016/j.biortech.2007.10.034

Lucas, E. O. (1984). Effect of population density on yield and dry matter partition of maize varieties in Nigeria. Indian Journal of agricultural Sciences, 54, 284-290.

Marschner, P., Solaiman, Z., \& Rengel, Z. (2005). Rhizosphere properties of Poaceae genotypes under P-limiting conditions. Plant Soil, 283, 11-24. https://doi.org/10.1007/s11104-005-8295-5

Meziane, D. (1997). Etude de la variation interspécifique de la vitesse spécifique de croissance et modélisation de l'effet des attributs morphologiques, physiologiques et d'allocation de biomasse (p. 164, PhD dissertation, Department of Biology, Université de Sherbrooke, Québec, Canada).

Miranda, M. S., Fonseca, M. L., Lima, A., de Moraes, T. F., \& Rodrigues, F. A. (2015). Environmental impacts of rice cultivation. American Journal of Plant Sciences, 6, 2009-2018. https://doi.org/10.4236/ ajps.2015.612201

Morgan, L. (2016). Cucumber Conundrums-Maximum Yield. Retrieved from https://www.maximumyield.com/ cucumber-conundrums/2/2639

Nakamura, R., Kachi, N., \& Suzuki, J.-I. (2008). Root growth and plant biomass in Lolium perenne exploring a nutrient-rich patch in soil. Journal of Plant Research, 121, 547-557. https://doi.org/10.1007/s10265008-0183-7 
Onana, O. L. G. (2006). Pratiques de fertilisation et caractéristiques des sols en zone maraîchère périurbaine de Yaoundé: cas des bas-fonds de Nkolondom (p. 73, Dissertation, Université de Dschang).

Peltre, C., Dignac, M. F., Derenne, S., \& Houot, S. (2010). Change of the chemical composition and biodegradability of the Van Soest soluble fraction during composting: A study using a novel extraction method. Waste Management, 30, 2448-2460. https://doi.org/10.1016/j.wasman.2010.06.021

Thomas, G. W. (1996). Soil pH and soil acidity. Methods of soil analysis. Part 3: Chemical Methods.

Wang, Z., Van Oost, K., Lang, A., Quine, T., Clymans, W., Merckx, R., ... Govers, G. (2014). The fate of buried organic carbon in colluvial soils: A long-term perspective. Biogeosciences, 11, 873-883. https://doi.org/ $10.5194 /$ bg-11-873-2014

\section{Copyrights}

Copyright for this article is retained by the author(s), with first publication rights granted to the journal.

This is an open-access article distributed under the terms and conditions of the Creative Commons Attribution license (http://creativecommons.org/licenses/by/4.0/). 